\title{
ポストゲノムシークエンス時代の薬理学 7
}

\section{ゲノムネットワーク}

\section{鈴木 善幸，池尾 一穂，五條堀 孝}

要約：ゲノムネットワークとは，ある生物種のゲノム にコードされているタンパク質や転写制御領域などと いった，いわゆる遺伝子情報が織り成す生体分子ネッ トワークの総体と定義され，それは転写制御ネットワ ーク，代謝ネットワーク，さらにはタンパク質ネット ワークなどといった部分ネットワークから構成されて いる。これらのネットワークの進化については，これ までの先駆的な研究により，その構成要素である夕ン パク質の獲得や喪失による進化史の一部が明らかにさ れるとともに，ネットワークの内部では部位によって 進化的保存度が異なることや，構成要素である夕ンパ ク質の進化がネットワークにおける他のタンパク質と の相互作用による影響を受けていることなどといった 進化機構の一部も明らかになってきている。ゲノムネ ットワークプロジェクトは，ヒトの様々な細胞におけ る遺伝子発現様式, DNA-タンパク質相互作用, さら にはタンパク質 - タンパク質相互作用などを網羅的に 解明し, データベースを構築, そしてそれを用いて様々 な研究を推進するという一大プロジェクトであり，ヒ 卜における様々な疾患の発現機序などが解明されるこ とが大いに期待されている。

\section{1. ゲノムネットワーク}

ゲノムネットワークとは，ある生物種のゲノムにコ ードされているタンパク質や転写制御領域などといっ た，いわゆる遺伝子情報が織り成す生体分子ネットワ 一クの総体と定義される(1)。この巨大な生体分子ネ ットワークは様々な部分ネットワークから構成されて おり，それらは例えば，DNAとタンパク質の相互作 用を介した転写制御ネットワーク，タンパク質と代謝
産物の相互作用を介した代謝ネットワーク，さらには タンパク質とタンパク質の相互作用を介したタンパク 質ネットワークなどである。我々の研究室ではこれま でこれらのネットワークに関して進化学的な視点に基 づいた研究を展開してきた。本稿においては，これら の研究から得られた成果のうちのいくつかを概説する とともに，現在進行中であるゲノムネットワークプロ ジェクトについて簡単に紹介する。

\section{2. 転写制御ネットワーク}

岩間と五條堀 (2) は，ヒトとマウスが進化的に分岐 した後，それぞれの系統において転写制御ネットワー クがどのように進化してきたのかを研究した。まず， ヒトとマウスの間で 3055 種類のタンパク質をコード する遺伝子についてオーソログの対を同定し，それら の翻訳開始点の上流 8000 塩基座位にわたる配列を比 較した。そして，遺伝子を上流配列の保存度の高い順 に並べ，1位からある順位までの間でどのような生物 学的機能を持った遺伝子がどれ位含まれているのかを 調べた（図 1)。ここで，遺伝子の生物学的機能とし ては，転写因子，発生関連遺伝子，シグナル伝達関連 遺伝子，細胞周期関連遺伝子，代謝関連遺伝子，そし て生合成関連遺伝子が用いられた。四 1 より，上流配 列の保存度の高い遺伝子のグループには，転写因子ゃ 発生関連遺伝子が他の遺伝子よりも統計的に有意に多 く含まれていることが分かった。これらの結果から， 岩間と五條堀 (2) は，発生に関与する転写因子の上流 には他の遺伝子よりも多くの転写因子が結合し，より 強い転写制御を受けていること，また，発生に関与す る転写制御ネットワークがその他の転写制御ネットワ

キーワード：ゲノムネットワーク，転写制御ネットワーク，代謝ネットワーク，タンパク質ネットワーク， 生体分子ネットワーク，ゲノムネットワークプロジェクト

国立遺伝学研究所 生命情報・DDBJ 研究センター（テ411-8540 静岡県三島市谷田 1111）

e-mail: tgojobor@genes.nig.ac.jp

原稿受領日：2005 年 3 月 31 日，会誌編集員依頼原稿

Title: Genome network

Author: Yoshiyuki Suzuki, Kazuho Ikeo, Takashi Gojobori 


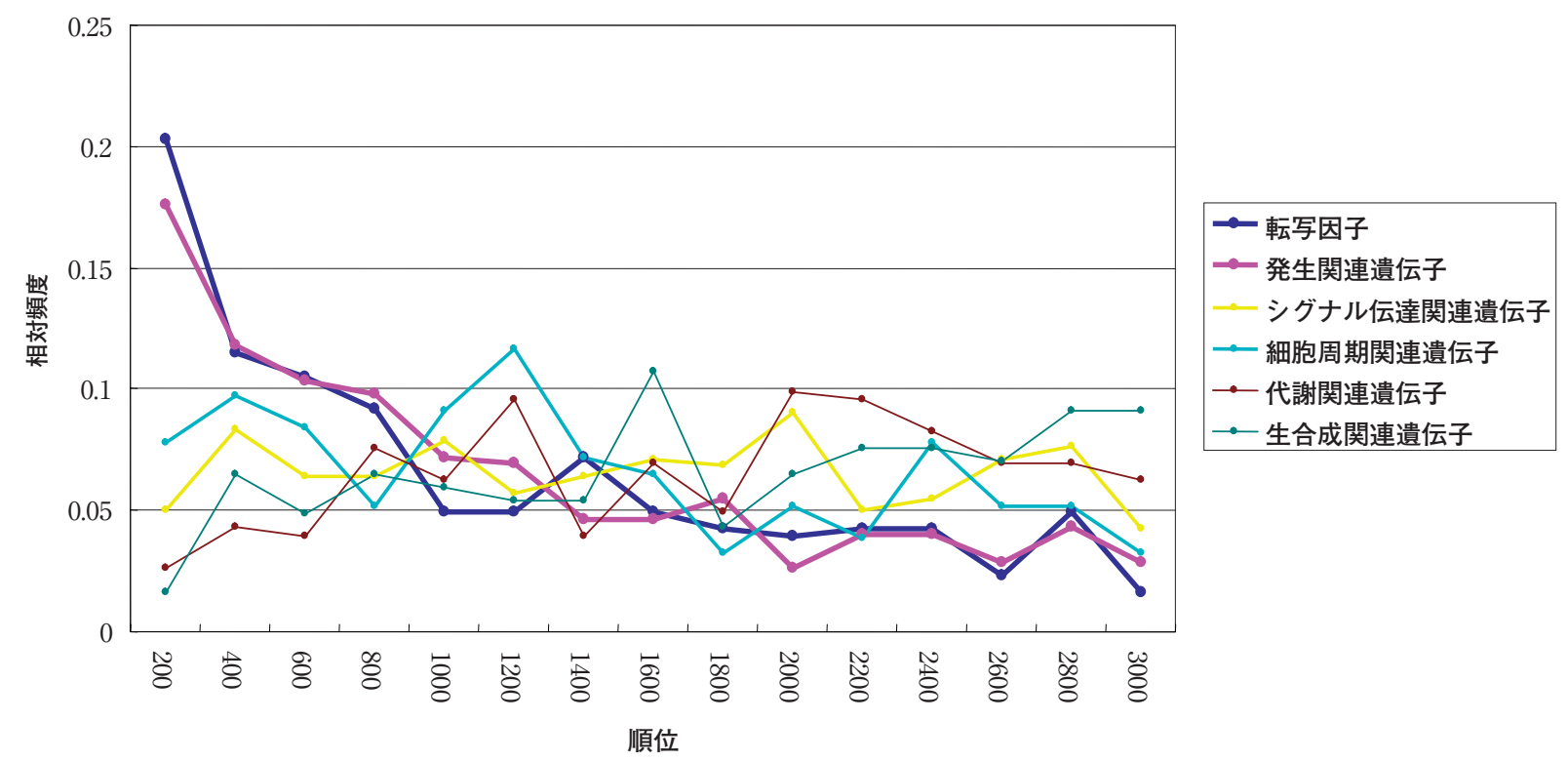

図 1 ヒトとマウスの間でタンパク質をコードする遺伝子のオーソログの対を, それらの翻訳開始点から上流 8000 塩基座位にわたる配 列の保存度の高い順に並べたとき, 1 位からある順位までの間でどのような生物学的機能を持った遺伝子がどれ位含まれているのかを示 した.これより，上位には転写因子と発生関連遺伝子が多く含まれていることが分かる. (文献 2 より改変)

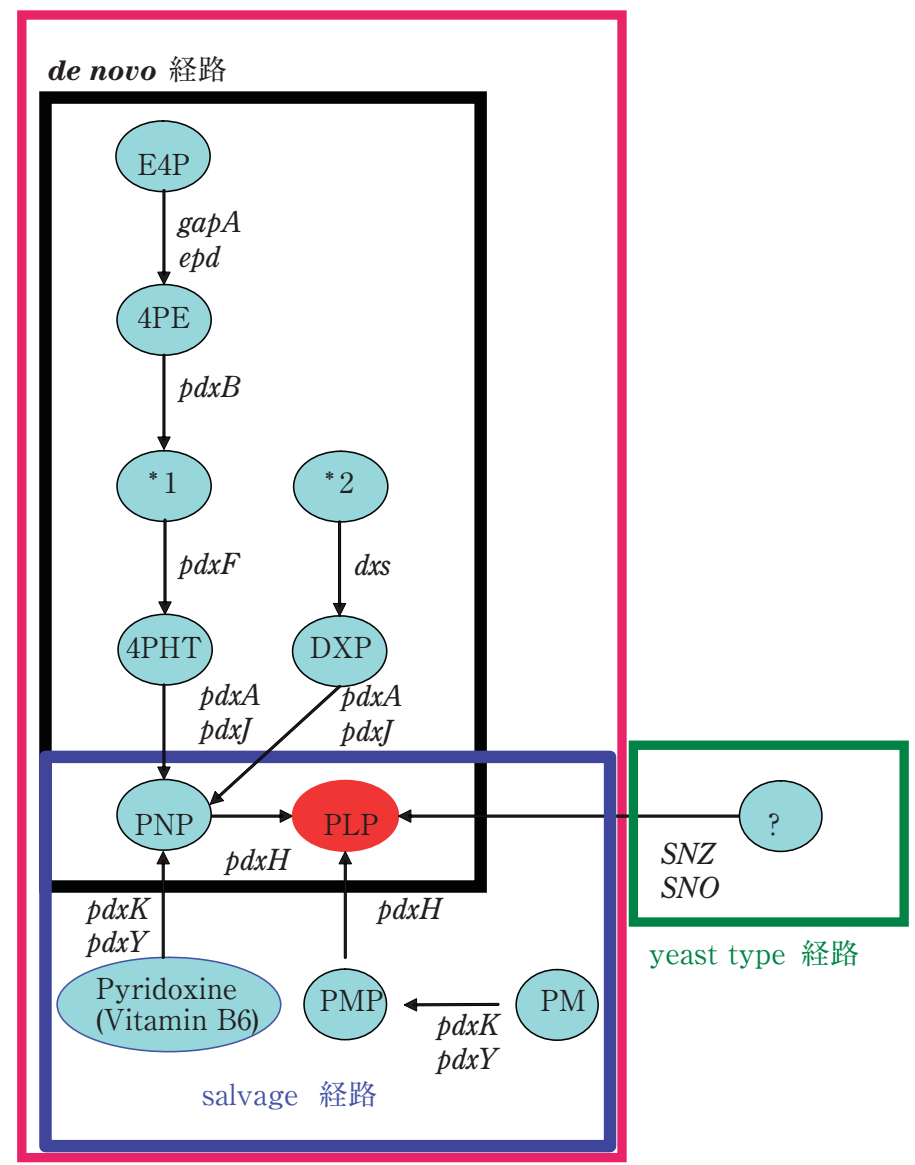

細菌で報告されている経路

出芽酵母で報告 されている経路

図 2 ビタミンB6 の代謝ネットワーク

代謝産物は楕円の中に示されている。 それぞれの矢印の傍にはその反応に関与する遺伝子が示されている.PLPは活性型ビタミンB6，*1は 3-hydroxy-4-phosphohydroxy- $\alpha$-ketobutyrate, そして*2は glyceraldehyde-3-phosphate を表している. (文献 3 より改变) 
ークよりも進化的に保存されていることを推測した。

\section{3. 代謝ネットワーク}

田中ら (3) は, ビタミン B6 の代謝ネットワーク（図 2）の真正細菌，古細菌，そして真核生物における進 化過程を研究した。図 2 に示すように，ビタミン B6 の代謝経路としては, 真正細菌において de novo 経路 と Salvage 経路が存在することが知られており，それ ぞれ 7 遺伝子, 2 遺伝子が関与していることが報告さ れている $(p d x H$ は両方の経路に関与している)。一方, 真核生物では，酵母や植物において yeast type 経路が 存在することが知られており，2 遺伝子が関与してい ることが報告されているが，面白いことに動物におい てはどの経路も存在せず，従ってビタミン B6 を生合 成することができない。

ゲノム配列が既知である真正細菌 97 種, 古細菌 16 種, そして真核生物 9 種の計 122 種の生物について, 上に 挙げたビタミン B6 の生合成に関与する計 10 種類の 遺伝子が存在しているかどうかを相同性検索を用いて 調べ，さらに 122 種の系統樹を用いてそれらの祖先種 に打ける 10 遺伝子の存在様式を推定した。ただしそ の際，進化の過程である遺伝子の獲得は 1 回だけしか 起こらなかったと仮定された。その結果，de novo 経 路に関与する 7 遺伝子は $\gamma$ - プロテオバクテリアの祖 先種で初めて揃ったと推定され, 従って de novo 経路 は $\gamma$-プロテオバクテリアが他の真正細菌から分岐し た後に新たに形成されたと推測された。一方，salvage 経路と yeast type 経路に関与する計 4 遺伝子は 真正細菌，古細菌，ならびに真核生物の共通祖先にお いて既に存在していたと推定され，従ってこれらの経 路も共通祖先において既に存在していたと推測された。 また同時に，これら 10 種類の遺伝子においては進化 の過程で多くの遺伝子衰失が起こったと推定された (表 1).

以上の結果から，田中ら (3) は，代謝ネットワーク の進化においては遺伝子の獲得と喪失，中でも特に衰 失が重要な役割を担っていると結論づけている.

\section{4. タンパク質ネットワーク}

牧野(4)は，タンパク質ネットワークの構成要素で あるタンパク質が，他のタンパク質との相互作用によ ってどのようにその進化機構に影響を受けているのか を研究した。まず，出芽酵母のゲノムに打いて，約 1 億年前に起こったと推定されているゲノム重複によっ て形成されたと考えられている重複遺伝子対の中から 254 対を取り出した。そしてそれぞれの重複遺伝子対
表 1122 種の生物の進化過程におけるビタ ミン B6 の生合成に関与する 10 種類の遺伝 子の喪失数 (文献 3 より改变)

\begin{tabular}{ccc}
\hline 遺伝子名 & $\begin{array}{c}\text { 左記遺伝子を } \\
\text { 持つ生物種数 }\end{array}$ & 遺伝子喌失数 \\
\hline$d x s$ & 76 & 10 \\
$g a p A$ & 103 & 3 \\
$p d x A$ & 46 & 13 \\
$p d x B$ & 18 & 2 \\
$p d x F$ & 67 & 24 \\
$p d x H$ & 52 & 14 \\
$p d x J$ & 42 & 8 \\
$p d x K$ & 45 & 20 \\
$S N O$ & 46 & 20 \\
$S N Z$ & 48 & 18 \\
\hline
\end{tabular}

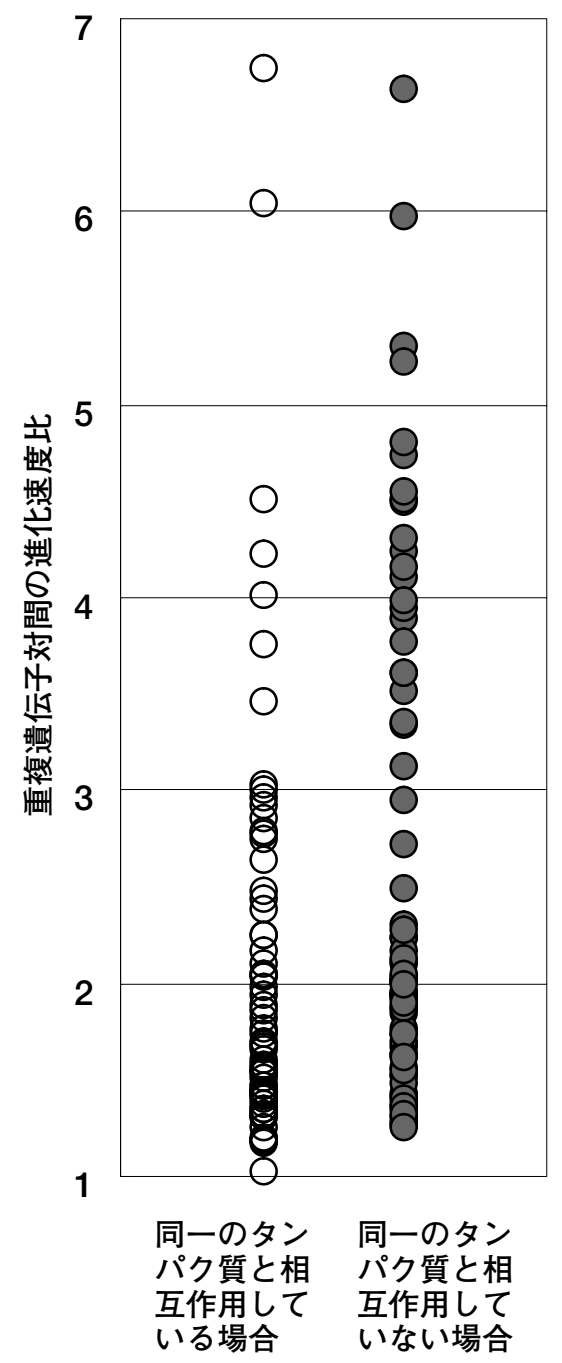

図 3 出芽酵母における重複遺伝子対間のアミノ酸置換速度の 比

比は，遅い方の進化速度を分母に，速い方を分子にして計算して いる. また, 重複遺伝子が同一のタンパク質と相互作用している 場合とそうでない場合に分けて比を表示してある。これより，重 複遺伝子対が同一のタンパク質と相互作用している場合の方がそ うでない場合よりもアミノ酸置換速度の違いが小さいことが分かる (文献 4 より改変) 
について，出芽酵母のゲノム重複以前に分岐したと考 えられている Kluyveromyces waltii におけるオーソロ グを同定した。

K. waltii に抒けるオーソログを, 出芽酵母の重複遺 伝子対とK. waltii に扔けるオーソログの 3 アミノ酸 配列を用いて作成された系統樹の外群と仮定すること によって, 出芽酵母の重複遺伝子対の間でそれらの重 複後の進化速度を比較することが可能となる.牧野 (4) は, 重複遺伝子対のうち, より多くのタンパク質と相 互作用をしている遺伝子の方が他よりも統計的に有意 にアミノ酸置換速度が遅いことを見出した。

次に, 254 対の重複遺伝子対を, 遺伝子対が同一の タンパク質と相互作用している場合とそうでない場合 に分類した。そしてそれぞれの遺伝子対について，ア ミノ酸置換速度が遅い方を分母，速い方を分子として 進化速度の比を計算した。すると, 重複遺伝子対が同 一のタンパク質と相互作用している場合の方がそうで ない場合よりもアミノ酸置換速度の違いが統計的に有 意に小さいことが分かった（図 3).

これらの結果から，牧野(4) は，それぞれのタンパ ク質ータンパク質相互作用がタンパク質の進化に対し て相加的に機能的制約を及ぼしていること, さらに類 似した生物学的機能を持つタンパク質はアミノ酸置換 速度も類似していることを推測した。

\section{5. 生体分子ネットワーク}

峯田ら (5) は, 左右相称動物において中枢神経系に 関与する生体分子ネットワークの進化について研究し た. 左右相称動物の中でも最も古くに分岐した動物の 1 種で，また最も原始的な中枢神経系を持つと考えら れているプラナリアにおいて, 他の生物種で神経系に 関与していることが既に知られている遺伝子に相同な 116 種類の遺伝子の EST をその体の前半部から同定 した。これら 116 種類の遺伝子が他の中枢神経系を持 つ生物種のゲノムに存在するかどうかを相同性検索を 用いて調べたところ, ヒト, ショウジョウバエ, 線虫 に拉いては 95\%以上の遺伝子が存在していることが 見出された. さらに, 中枢神経系を持たない出芽酵母 やシロイヌナズナに抒いても $30 \%$ 以上の遺伝子が存 在していることが見出された。これらの結果から, 峯 田ら (5) は，中枢神経系を形成する生体分子ネットワ ークは左右相称動物の共通祖先において既に存在して おりまた中枢神経系を形成する遺伝子は神経系が形 成されるよりもずっと以前に存在していたものが再利 用されたと推測した。

最後に, 小倉ら (6) は, ヒトと夕コにおいてどのよ
うに独立してカメラ眼を形成する生体分子ネットワー クが収斂進化してきたのかを研究した。成体の夕コの 眼で発現している 1052 種類のタンパク質をコードす る遺伝子の EST 同定し, それを 13,303 種類のヒト の眼で発現していることが知られている遺伝子と相同 性検索を用いて比較した。そその結果, 1052 種類の夕 コの眼で発現していた遺伝子のうち約 70\%はヒトの 眼でも発現していることが分かった。また 1052 遺伝 子のうちの約 $97 \%$ はコとヒトの共通祖先において 既に存在していたと推測された。 以上の結果から，小 倉ら (6) は, カメラ眼の発生に必要な遺伝子はヒトと タコの共通祖先で既に揃っていたと結論づけた。

\section{6. ゲノムネットワークプロジェクト}

以上の研究は, ゲノムネットワークの先駆的研究と 言えるものである.ゲノムネットワークに関してより 広範な研究を行㧍うとするとき, いろいろな生物学的 現象について横断的に役立つ情報を提供しょうとする 網羅的研究を横軸研究とすると (1), この横軸研究を しっかり行う必要がある. 現代の生物学的研究は, 横 軸研究の結果として構築されたデータベースを最大限 に活用しながら縦軸研究とでも言うべき個別研究を推 進していくというスタイルになってきている，従って， その基盤となる横軸研究をさらに拡充させ, 利用しゃ すいデータベースを構築することが最重要課題の一つ となっている。

ゲノムネットワークプロジェクトは, 理化学研究所 と国立遺伝学研究所が中心となり, ヒトの様々な細胞 における遺伝子発現様式, DNA- タンパク質相互作用, さらにはタンパク質 - タンパク質相互作用などを網羅 的に解明し，データベースを構築するといった横軸研 究, そしてそれを用いて様々な縦軸研究を推進する, という一大プロジェクトである。これにより，ヒトに おける様々な疾患の発現機序などが解明されることが 大いに期待されている.

謝辞：本稿を執筆するに当たり, 岩間久和博士, 田中 剛 博士, 牧野能士博士, 峯田克彦博士, ならびに小倉 淳博 士にはコメントを頂きました。また, 岩間久和博士, 田 中 剛博士, ならびに牧野能士博士には, それぞれのご研 究に関する図や表をご提供頂きました。ここに感謝申し上 げます。 


\section{文}

献

1) 蛋白質核酸酵素. 2004;49:2617-2619.

2) Iwama H, et al. Proc Natl Acad Sci USA. 2004;101:1715617161.
3) Tanaka T, et al. Mol Biol Evol. 2004;22:243-250.

4) Makino T. Evolution of protein-protein interaction network. Ph.D. dissertation, The Graduate University for Advanced Studies, Hayama. 2004.

5) Mineta K, et al. Proc Natl Acad Sci USA. 2003;100:7666-7671.

6) Ogura A, et al. Genome Res. 2004;14:1555-1561.

\section{著者プロフィール}

鈴木 善幸（すずき よしゆき）

国立遺伝学研究所 生命情報・DDBJ 研究センター, 助手, 博士 (医学) ・博士 (理学)

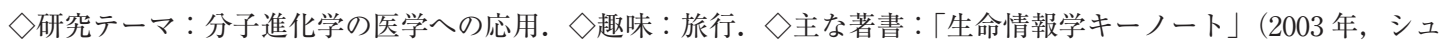
プリンガー・フェアラーク東京）（監訳）

池尾一穂(いけ打 かずほ)

国立遺伝学研究所 生命情報・DDBJ 研究センター, 助教授, 博士 (理学).

$\diamond$ 研究テーマ: 進化発生学, 比較進化学, 情報生物学. 趣味：海水魚飼育.

$\diamond$ 主な著書 :「分子進化実験法」(1993 年, 日本生化学会),「機器分析概論」(1993 年, 日本生化学会),「ゲノムか らみた生物の多样性と進化」(2003 年, シュプリンガー・フェアラーク東京),「生命情報学」(2003 年, シュプリン ガー・フェアラーク東京),「生命情報学キーノート」(2003 年, シュプリンガー・フェアラーク東京) (監訳)

五條堀 孝（ごじょうぼり たかし）

国立遺伝学研究所 生命情報・DDBJ 研究センター, センター長・教授, バイオ産業情報化コンソーシアム 生物情 報解析研究センター 副センター長・グループリーダー, 理学博士

○研究テーマ: 分子進化学, 集団遺伝学, 情報生物学 (バイオインフォマティクス). 趣味：旧車観賞.

○主な著書 :「人間は生命を創れるか」(1995 年, 丸善ライブラリー),「ゲノムからみた生物の多椂性と進化」(2003 年, シュプリンガー・フェアラーク東京),「生命情報学」(2003 年, シュプリンガー・フェアラーク東京)
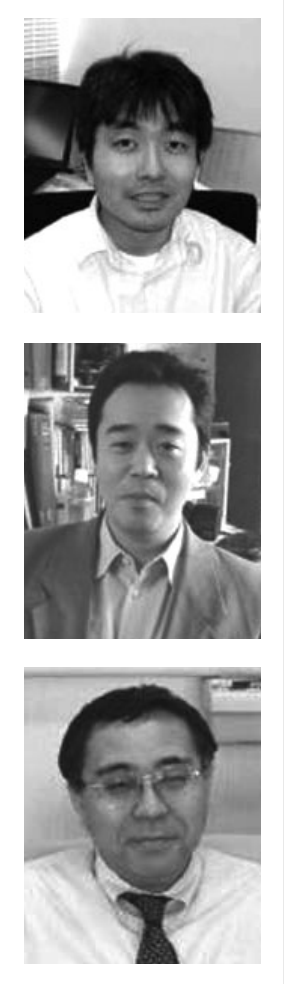